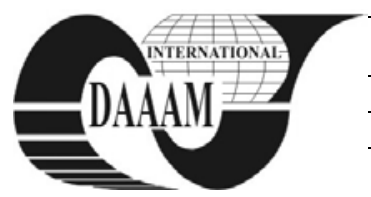

Annals of DAAAM for 2011 \& Proceedings of the 22nd International DAAAM Symposium, Volume 22, No. 1, ISSN 1726-9679 ISBN 978-3-901509-83-4, Editor B. Katalinic, Published by DAAAM International, Vienna, Austria, EU, 2011 Make Harmony between Technology and Nature, and Your Mind will Fly Free as a Bird Annals \& Proceedings of DAAAM International 2011

\title{
PILLARS IN FINANCIAL AND ACCOUNTING RISK MANAGEMENT
}

\author{
DANESCU, T[atiana] \& DUCU, C[orina] - M[aria]
}

\begin{abstract}
Financial and accounting risk management is a key issue without which an organization cannot achieve the set goals. Given this context and the permanent desire to increase performance, we ask the following question: what are the essential pillars that provide financial and accounting risk management?
\end{abstract}

Key words: financial and accounting risk, internal control, internal audit, risk management, corporate governance

\section{INTRODUCTION}

Financial and accounting risks are ubiquitous in organizations' activity. Over time solutions have been sought as to what constitutes the way in which the organizations' risks can be controlled in order to remove their adverse effects. In this sense, different activities have been identified to ensure the compliance with the requirements imposed by various laws and regulations, as well as the requirements established by the policies of the respective entities. Such insurance activities that may be organized under the responsibility of the corporate governance of an organization have led to internal control and internal audit. The internal control has been called a dynamic process that involves all levels of management aiming to obtain reasonable assurance that the activities of the entity will be accomplished. Since the internal control that ensures the perfect operation of an organization is very expensive, and therefore impractical, the internal control objectives are relative and unabsolute in what the result of a reasonable assurance is regarded (Danescu, 2011). Therefore, the reform process in organizational management, particularly that of the public sector organizations, greatly emphasizes the organization of the internal audit (Mihailescu, 2010).

The internal audit activity, as an independent and objective activity, ensures an entity about the degree of control over its operations, whose purpose is "to assess the accuracy and truthfulness of information, particularly the accounting ones; to ensure the physical and accounting security of the operations; guarantee the patrimony; to efficiently judge the effectiveness of the information system" (Renard, 2003).

Lemant Olivier, claims that "the purpose of internal audit is not to write reports, but to support the organization, the enterprise in reaching objectives, even if it implies the performance of a report with recommendations" (Lemant, 2002).

The French Institute of Internal Auditors believes that internal auditing within a firm is "an independent activity of assessment regarding the operational control".

The definition given in the International Standards for the Professional Practice of Internal Auditing claims that "internal auditing is an independent business designed to help improve the effectiveness of risk management, control and governance processes” (IIA, 1999).

\section{RESEARCH METHODOLOGY}

The research conducted to reach the established objective focused on comprehensive documentation in the literature, in the Romanian regulations applicable in Romania to the organizations that manage venture capital, in the practice adopted under the responsibility of those charged with corporate management to collect information for the analysis of concepts, methods and procedures, which represent an object of the activities that contribute to managing financial and accounting risks within various entities. The approach has focused on the internal control activities, risk management and internal audit. For all these, the authors have used the description, implicit and explicit comparisons, activity segregation, activity compilation, analyses upon the policies and procedures that identify and monitor the financial and accounting risks imposed or suggested by the regulations applicable in Romania, and adopted by the option of the entities.

An important place in risk management was taken by the reasons and the motivations that have been found and the conclusions that we have formulated and are relevant to the established objective.

\section{TRIPARTITE RELATIONSHIP: INTERNAL CONTROL - RISK MANAGEMENT - INTERNAL AUDIT}

The global changes, as well as the existence of a large number of participants in the economic life of the organizations that manage venture capital require risk management, in general, and financial and accounting risk management, in particular, through efficient strategies of identification, evaluation, treatment and management. The mission taken on by the organizations becomes more and more difficult in the context in which the participants at the organizational life have their own interests that are divergent in many cases, sometimes even contradictory (Danescu, 2007).

From the undertaken research, we believe that the adoption and application of such a strategy can not be achieved without the contribution of internal control, risk management and internal audit. They describe the practical connection with the interrelated elements that define a risk management network, whose importance is acknowledged by the corporate leaders of the organization who can invest in an important instrument to accomplish the mission of the organization which manages venture capital.

An important target of corporate governance and management in this network should be the internal control, mainly the one that focuses on the constant organizational risks. The organizational activities will be directed towards the accomplishment of the objectives established in the organization through proper planning and organization of internal control. Therefore, we believe that internal control 
should be primarily seen as an architectural range of policies which requires the adoption of applicable procedures that provide information and recommendations regarding the requirements to be met by all personnel of the organization in order to conduct the activities in the best conditions for the proposed objectives. Secondly, we believe that internal control should be invested in a well-defined hierarchical structure to provide oversight of how the activities are conducted.

With reference to the internal control objectives we can mention: the elimination of irregularities and fraud reduction, directing management towards efficiency, effectiveness and economy; managing activities that are subject to risks, implementing a culture regarding the control environment within the entity; being aware of the importance of the control system for the entity staff.

According to its objectives, internal control is a dynamic process which must continuously change according to the economic and social environment tailored to the activities in the organization.

Being permanently available to the management, the internal control tools and techniques focus on risk management activities, which are closely monitored through internal audit.

The purpose of internal audit implementation within the organization is not only to provide reasonable assurance regarding the compliance with laws, regulations and policies, but also to identify the risks of the organization, to make recommendations regarding the adoption of the best risk management solutions, management in general, and financial and accounting risks, in particular.

The organization of internal control and internal audit is influenced by the managers' style, by the risks, by the organizational structure of a company. In Romania, according to the current legislation, there are implemented risk management processes, both in the public sector organizations and in other sectors. The organizations are faced with a multitude of positive and negative, internal and external risks that can never be fully considered. Risk management, in particular financial and accounting risk management, is a process that requires a lot of effort, but it is an essential component in the success of the entity, helping to increase the added value. Every manager must face various risk management problems, because, otherwise, their work will have negative results.

Risk management requires the completion of certain steps, such as (Ghita, Briciu, 2009):

- risk identification;

This activity aims to detect and record all risks. Once risks have been identified they must designate people to manage and continuously monitor those risks.

- risk assessment;

This means to identify and analyze the internal and external factors that positively or negatively affect the organization's objectives. Risk assessment should be an ongoing process because they are constantly changing due to the environmental changes, pursuing new goals, the emergence of new participants in the organization.

- risk control.

It involves taking the control and other activities in response to the identified risks.

- risk analysis and reporting carried out in order to identify the hazards of the audited entity, to prevent, eliminate or minimize them; the internal control activity evaluation of the audited entity, as well as management reports.

Both internal control and risk management try to identify and manage financial and accounting risks in order to eliminate financial losses and to have a clear image of the accounting system implemented within the respective entity.
Through the activities they develop, the internal auditors have the responsibility to monitor the internal control system of an organization, to recommend policy makers how to maintain risks at an acceptable level so as to ensure the smooth functioning of the organization and achieve the established goals.

In this sense, we identify a tripartite relationship between internal control, internal audit and an organization's risk management. The relationship internal control - internal audit risk management offered through a mutual inter-conditioning in order to manage risks properly, and also through the specificity of the internal audit regarding the assessment of the internal control and risk management processes achieved by the internal audit is presented in Figure 1.

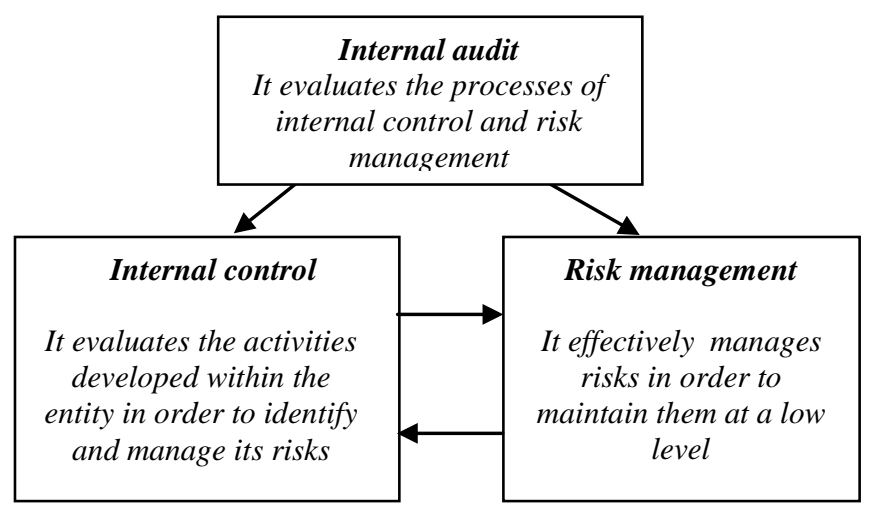

Fig. 1. Pillars of financial and accounting risk management Source: Research of the authors

\section{CONCLUSIONS}

As it results from the conducted research, we consider that there are three essential pillars of risk management within an organization, especially those of financial and accounting risk management. These pillars are internal control, risk management and internal audit. The three pillars are not elements that operate independently, but they are in a close interdependence which defines a tripartite relationship: internal control - internal audit - risk management that can be used by an organization to manage its financial and accounting risks in order to provide assurance in terms of achieving the declared objectives.

\section{REFERENCES}

Danescu, T. (2007). Financial Audit - Convergences between Theory and Practice, Irecson Publishing House, Bucharest, pp.29-41

Danescu, T. (2011).Internal audit. Course notes, "Petru Maior" University Publishing House, Targu Mureş, pp.14- 26

Ghita, M.; Briciu, S. coord. (2009). Corporate governance and internal audit, Aeternitas Publishing House, Alba Iulia, pp. 237-258, processing and adaptation

Lemant, O. (2002). L'audit interne, Editeur E-theque, pp.12

Mihailescu, I. (2010). Audit and internal control, Independenta Economica Publishing House, Pitesti, pp.15

Jacques, R. (2002). Theory and practice of the internal audit, Editions d'Organisation, Paris, France, translated into Romanian by a PHARE project, under the coordination of the Department of Public Finance, Bucharest, 2003, pp 15

***Professional Standards of Internal Audit http://www.aair.ro/new4/fisiere/standarde_romana/Standar de_IIA_rom.pdf, site accessed on 20.03.2011) 